Teologia i Moralność, volumen 12(2017), numer 2(22)

doi: 10.14746/tim.2017.22.2.4

\author{
ANDRZEJ DERDZIUK \\ Katolicki Uniwersytet Lubelski Jana Pawła II \\ Wydział Teologii
}

\title{
Modlitwa jako narzędzie budowania nowej kultury życia
}

Uznanie modlitwy za narzędzie budowania nowej kultury życia opiera się na stwierdzeniu, że obecnie troska o ochronę życia dzieci poczętych oraz nieuleczalnie chorych i umierających jest elementem walki duchowej. Jan Paweł II w sposób bardzo wyraźny wskazywał na modlitwę jako na oręż w walce o świętość życia i proponował wysławianie Ewangelii życia każdemu człowiekowi pragnącemu uznać wartość ludzkiej egzystencji. Sam papież prowadził swoje rozważania w encyklice jako medytację nad cudem życia i w trakcie dokumentu wiele razy wskazywał na potrzebę modlitwy oraz sam uwielbiał Boga za Jego dzieło stwórcze. Papieska modlitwa w Evangelium vitae została podsumowana przez końcowe zwrócenie się do Maryi.

\section{Duchowy wymiar zmagania o cywilizację życia}

Obecnie trwa wojna kulturowa, która ma też wymiar duchowy i toczy się nie tylko na poziomie konfrontacji między ludźmi, ale dotyczy współczesnej odsłony walki dobra i zła. Do tej konfrontacji można odnieść słowa z Księgi Powtórzonego Prawa: „Biorę dziś przeciwko wam na świadków niebo i ziemię, kładąc przed wami życie i śmierć, błogosławieństwo i przekleństwo. Wybierajcie więc życie, abyście żyli wy i wasze potomstwo, miłując Pana, Boga swego, słuchając Jego głosu, lgnąc do Niego" (Pwt 30,19-20) oraz Księgi Syracha „Przed ludźmi życie i śmierć, co ci się podoba, to będzie ci dane” (Syr 15,17). Metafizyczny wymiar zmagania o życie, które ujawnia się jako opowiedzenie po stronie życia lub śmierci, wskazuje na potrzebę dostrzeżenia modlitwy jako najbardziej skutecznego sposobu poszukiwania narzędzi zwyciężania. 
Na ten temat wypowiedział się Jan Paweł II w Liście apostolskim Gratissimum sane, gdzie stwierdził „Oto bowiem - jeśli z jednej strony istnieje «cywilizacja miłości», to równocześnie też zachodzi możliwość antycywilizacji destrukcyjnej, co niestety w naszej epoce stało się faktem dokonanym o bardzo szerokim zasięgu" (LdR 13). Odnosząc się do tej kwestii w encyklice poświęconej obronie życia, papież Polak napisał: „Istnieją oczywiście ogromne dysproporcje między licznymi i potężnymi środkami, w jakie są wyposażone siły działające na rzecz «kultury śmierci», a tymi, którymi dysponują obrońcy «kultury życia i miłości». My jednak wiemy, że możemy ufać w pomoc Boga, dla którego nie ma nic niemożliwego" (EV 1000).

Utożsamienie troski o życie z zabieganiem o więź z Bogiem jest tak wielkie, iż ks. Jerzy Bajda ośmielił się stwierdzić, że „kto działa dla dobra życia, dla jego obrony, działa razem z Bogiem; kto działa przeciw życiu, występuje przeciw Bogu"1. Nie ma więc możliwości zachowania neutralności wobec Boga, gdy atakuje się życie. Zarazem nie ma możliwości toczenia zwycięskiej batalii o Ewangelię życia bez modlitwy, będącej otwieraniem się na dary, których Ojciec z nieba udziela swoim dzieciom (por. Mt 7,11).

W rozmowie z Vittoriem Messorim Jan Paweł II wyznał, że

Najprostszym sposobem uobecniania w świecie Boga i Jego zbawczej miłości jest właśnie modlitwa. Bóg zawierzył ludziom zbawienie ludzi, zawierzył ludziom Kościół, a w Kościele całe odkupieńcze dzieło Chrystusa. Zawierzył każdemu każdego i wszystkich. Zawierzył każdemu wszystkich i wszystkim każdego. Ta świadomość musi wciąż znajdować odzwierciedlenie w modlitwie Kościoła ${ }^{2}$.

Modlitwa bowiem jako sposób przywoływania Boga i otwierania się człowieka na Jego obecność sprawia, że Syn Boży w sposób realny ujawnia się pośród ludzi. Bóg, wychodząc na spotkanie człowieka cierpiącego, objawia się jako miłosierny Ojciec i podnosząc z upadku, wzywa do większego zaufania w zwycięstwo dobra w świecie.

Dlatego papież w przywoływanym już dokumencie usilnie zachęcał: „Niechaj ten List do Rodzin stanie się zaproszeniem Chrystusa do każdej ludzkiej rodziny, a poprzez rodzinę zaproszeniem Go do wielkiej rodziny narodów, abyśmy z Nim razem mogli powiedzieć w prawdzie: «Ojcze nasz!» Trzeba, ażeby modlitwa stała się dominantą Roku Rodziny w Kościele: modlitwa rodziny, modlitwa za rodziny, modlitwa z rodzinami” (LdR 4). Przez modlitwę bowiem „człowiek odkrywa w sposób najprostszy i najgłębszy zarazem wła-

${ }^{1}$ J. Bajda. Obrona życia $w$ duchu nadprzyrodzonym - w ujęciu Jana Pawła II, http://dadp.nie pokalanow.pl/da_u_jp2/da_u_jp2.2.html [dostęp: 06.02.2017].

${ }^{2}$ Por. Przekroczyć próg nadziei. Jan Pawet II odpowiada na pytania Vittoria Messoriego, Lublin 1994, s. 39. 
ściwą sobie podmiotowość: ludzkie «ja» potwierdza się jako podmiot najłatwiej wówczas, gdy jest zwrócone do Boskiego «Ty»" (LdR 4).

\section{Znaczenie modlitwy dla ochrony życia}

Wzywając do modlitwy jako sposobu angażowania się w krzewienie i obronę wartości życia, Jan Paweł II ukazywał jej wyzwalający charakter, gdyż modlitwa pozwala człowiekowi stanąć w prawdzie i przez to ukazuje mu realne miejsce we wszechświecie. Dzięki właściwemu odniesieniu do Boga człowiek dostrzega, że nie jest skazany tylko na siebie samego, ale może liczyć na pomoc Tego, który stworzył świat. Zarazem człowiek dochodzi do odkrycia, że nie jest samowystarczalny i dlatego - przeżywając upadki oraz doświadczenie słabości - nie upada na duchu, bo wie, że jest tylko jednym ze stworzeń, które otrzymało tchnienie życia od Boga. Odrzucenie fałszywego antropocentryzmu nie musi prowadzić do poczucia zagubienia $\mathrm{W}$ wielkim wszechświecie, gdyż człowiek w modlitwie odkrywa, że jest dzieckiem Boga i może z ufnością wołać „Abba, Ojcze” (Rz 8,15).

Odnosząc swe sprawy do Boga, człowiek pamięta o potrzebie liczenia na Jego pomoc i jednocześnie zdaje sobie sprawę z własnej ograniczoności. Wezwany do wielkich rzeczy, chrześcijanin odkrywa prawdziwą ich miarę w świetle wiary i buduje społeczność ludzką na miarę odniesienia do ewangelicznego ideału. Stąd też Jan Paweł II wołał w Koszalinie, że „tylko w mocy pierwszego przykazania Dekalogu można myśleć o prawdziwym humanizmie. Bez Boga pozostają ruiny ludzkiej moralności"3.

Modlitwa przez to staje się skuteczna, że jest czymś więcej niż tylko rozmową z Bogiem, ale jawi się jako poruszenie ludzkiego serca i ukierunkowuje całą egzystencję człowieka na podtrzymywanie więzi z Bogiem. Modlitwa pojęta jako sposób i styl życia, odnosząca całą aktywność osoby ludzkiej do Boga, prowadzi do przyjęcia za swoje postulatów miłości przyniesionej na świat przez Jezusa i rozlewanej w sercach przez Ducha Świętego. Chrześcijanin wzywający w Duchu Boga jako miłosiernego Ojca, identyfikuje się w pełni ze zbawczym zamiarem Stwórcy wobec każdego stworzenia i przyznaje prawo do istnienia wszystkiemu, co wyszło z rąk Bożych.

Zachęcając nade wszystko do wysławiania dzieł Boga, Jan Paweł II w encyklice Evangelium vitae zwracał uwagę na konieczność dostrzeżenia najpierw miłości samego Stwórcy, a potem wartości Jego dzieł. Dlatego też wzywał członków Kościoła: „Także my, wzorem Psalmisty, w codziennej modlitwie

${ }^{3}$ Jan Paweł II, Homilia podczas Mszy świętej. Koszalin kościót Świętego Ducha 1.06.1991, „L'Osservatore Romano” 11(1991) nr spec, s. 8. 
osobistej i wspólnotowej chwalimy i błogosławimy Boga, naszego Ojca, który utkał nas w matczynym łonie, widział nas i umiłował, gdyśmy powstawali w ukryciu (por. Ps 139[138],13.15-16), i przepełnieni ogromną radością wołamy: «Dziękuję Ci, że mnie stworzyłeś tak cudownie, godne podziwu są Twoje dzieła. I dobrze znasz moją duszę» (Ps 139[138],14)" (EV 84).

Zachwyt nad życiem jest możliwy dzięki temu, że człowiek odkrywa, iż jest otoczony miłością i może liczyć na Bożą opatrzność. Dlatego Jan Paweł II stwierdził: ,śmiertelne życie - mimo jego trudów, jego niezbadanych tajemnic, cierpień i nieuniknionej przemijalności - jest czymś niezwykle pięknym, cudem zawsze nowym i zachwycającym, wydarzeniem godnym tego, by opiewać je z radością i uwielbieniem" (EV 84). Modlitwa nie usuwa trudów życia ani nie staje się formą ucieczki od codziennych problemów, ale uzbrajając człowieka mocą z wysoka, wskazuje na możliwości pokonania napotykanych wyzwań, gdyż opiera się na wierze, że Chrystus Zmartwychwstały udziela Ducha Świętego swoim uczniom.

Modlitwa pojęta jako czuwanie oznacza, że

człowiek nie zamyka się w chwili teraźniejszej i nie poddaje się konkretnym sprawom, lecz kieruje wzrok ponad rzeczy przemijające i przynaglenie. Chodzi o to, by kierować ku Bogu niczym nie skrępowany wzrok, pozwalający otrzymać od Niego miarę właściwego postępowania i zdolność do niego. Czuwanie oznacza przede wszystkim otwartość na dobro, prawdę i Boga pośród nieobjaśnialnego często świata i pośrodku mocy zła. Oznacza to, że człowiek z całej siły i z wielką trzeźwością myślenia stara się czynić to, co słuszne, że nie kieruje się w życiu własnymi pragnieniami, lecz drogowskazami wiary ${ }^{4}$.

Jan Paweł II, przypominając potrzebę modlitwy, wskazywał na realne zagrożenia obecnej doby i stawiał przed oczyma człowieka zadania przemieniania świata, które rozpoczyna się od przemiany własnego serca. Wyraził to między innymi w słowach:

przynaglony głęboką troską o los każdego człowieka, powtarzam dziś wobec wszystkich to, co powiedziałem do rodzin spełniających swoje trudne zadania pośród zagrażających im niebezpieczeństw: pilnie potrzebna jest wielka modlitwa za życie, przenikająca cały świat. W ramach specjalnych inicjatyw oraz w codziennej modlitwie niech każda chrześcijańska wspólnota, każdy ruch i stowarzyszenie, każda rodzina i każdy wierzący zanoszą żarliwe błaganie do Boga, Stwórcy i Miłośnika życia. Jezus pokazał nam, że modlitwa i post to najważ-

${ }^{4}$ J. Ratzinger, Jezus z Nazaretu. Studia o chrystologii, t. 1, cz. 1, tłum. M. Górecka, W. Szymona, Lublin 2015, s. 579. 
niejsza i najskuteczniejsza broń przeciw mocom zła (por. Mt 4,1-11) i pouczył swoich uczniów, że niektóre złe duchy można wypędzić tylko w ten sposób (por. Mk 9,29). Zdobadźmy się zatem na pokorę i odwagę modlitwy i postu, aby sprowadzić moc z Wysoka, która obali mury oszustwa i kłamstwa, zasłaniające przed oczyma wielu naszych braci i sióstr niegodziwość czynów i ustaw wrogich życiu i wzbudzi $\mathrm{w}$ ich sercach postanowienia i zamiary inspirowane cywilizacją życia i miłości (EV 100).

Papież miał świadomość, że człowiek może zostać zwiedziony przez kłamstwa dotyczące życia, które dziś przyjmują formę epatowania współczuciem przez nagłaśnianie przypadków uciążliwego cierpienia. Kultura śmierci, rzekomo pochylająca się nad doświadczeniem bólu, nie dostrzega go jednak w perspektywie wieczności i nie docenia miłości, która pomaga przezwyciężyć trud okaleczonej egzystencji przez odkrycie sensu w perspektywie zaproszenia do wiecznej komunii z Bogiem. Modlitwa chrześcijanina nie może zatem stać się elementem alienującym z codziennego życia i niedostrzegającym realności dramatu zmagania się z cierpieniem. Uczeń Chrystusa złączony z Mistrzem dąży do eliminacji bólu, przez jego pokonanie, a nie przez uśmiercanie cierpiącego człowieka. Dlatego modlitwa musi łączyć się ze szczerym współczuciem, które prowadzi do konkretnego czynu służebnej miłości.

\section{Papieska kontemplacja tajemnicy życia}

Jan Paweł II nie poprzestawał tylko na zachęcie do modlitwy, ale wskazywał konkretne jej formy i okoliczności, w których winna być realizowana. Zamieszczając w tekście encykliki liczne wezwania do modlitwy, sam prowadził w treści dokumentu modlitewną kontemplację tajemnicy świętości życia i realizował postulat odnoszenia ludzkiego życia do jego Twórcy. Szczególnie w czwartym rozdziale dokumentu wybrzmiewa wysławianie Ewangelii życia jako sposób ukazywania jej wartości i droga uczenia się szacunku dla każdego przejawu ludzkiej egzystencji. Kontemplacja, jawiąc się jako jedynie właściwa postawa wobec Boga, winna ożywiać dążenia człowieka do budowania lepszego świata, gdyż „osią każdej kultury jest postawa wobec największej tajemnicy: tajemnicy Boga" (EV 96).

Definiując kontemplację, papież stwierdził, że ,jest to postawa tego, kto widzi życie w całej jego głębi, kto dostrzega jego bezinteresowność i piękno oraz przyjmuje je jako wezwanie do wolności i odpowiedzialności. Jest to postawa tego, kto nie próbuje zagarnąć dla siebie rzeczywistości, ale przyjmuje ją jako dar, odkrywając w każdej rzeczy odblask Stwórcy, a w każdej osobie Jego żywy obraz" (EV 83). Przez modlitwę człowiek upodabnia się do Boga 
w Jego pragnieniu otoczenia ludzkości bezinteresowną miłością, która wyzwala z zaślepiającego egoizmu i prowadzi do postawy służby 5 .

Proponując itinerarium duchowego wzrastania, Jan Paweł II kreślił na kartach Evangelium vitae drogę rozważania tajemnic życia Bożego, zapraszając do podążania nią swoich czytelników. Papież rozpoczął od adoracyjnego zatrzymania się nad tajemnicą stworzenia, by potem przejść do rozważania tajemnicy wcielenia i odkupienia ujawniających wartość ziemskiego życia człowieka, które zostało wybrane i ukochane przez Syna Człowieczego (por. EV 84). Ostatnim etapem tej modlitwy jest medytacja nad figurą i rolą Matki Bożej w tajemnicy Kościoła, czego podsumowaniem są końcowe wezwania skierowane do Najświętszej Maryi Panny.

Ziemskie stworzenia ujawniają wielkość ich Twórcy określanego mianem „Miłośnika życia” (EV 100). Dzieła stworzone jawią się jako dar udzielony człowiekowi po to, by mądrze z nich korzystał przez wykorzystywanie ich potencjału do służenia bliźniemu. Ludzka istota bowiem otrzymała wolność, by przez nią realizować swoje powołanie, ,które dokonuje się przez dar z siebie i otwarcie się na drugiego człowieka" (EV 19). Przez kontemplację tajemnicy Trójcy Świętej chrześcijanin odkrywa siebie jako istotę relacyjną, potrzebującą drugiego „ty” jako swoistego dopełnienia własnego szczęścia ${ }^{6}$.

Odwołując się do tajemnicy Bożego Narodzenia, Jan Paweł II przytoczył słowa bł. Pawła VI i stwierdził, że Chrystus, stając się człowiekiem, jest początkiem życia i jego jedynym źródłem, które każdy chrześcijanin winien kontemplować i wielbić (EV 84). W perspektywie tego, że Bóg stał się człowiekiem, ujawnia się wartość ludzkiego życia, które zostało wyniesione do godności dziecka Bożego. „W każdym rodzącym się dziecku i w każdym człowieku, który żyje lub umiera, dostrzegamy obraz Bożej chwały: tę chwałę wysławiamy w każdym człowieku, znaku Boga żywego, ikonie Jezusa Chrystusa" (EV 84).

Mimo grzechu poniżającego człowieka i zniewalającego go swoją mocą uwodzenia Bóg nie zrezygnował z udzielania ludzkości swoich darów i posłał na świat swojego Syna. Objawienie miłosiernej miłości w Jezusie Chrystusie ukazuje szacunek dla życia ludzkiego, którego wartość Odkupiciel potwierdza swoją śmiercią i zmartwychwstaniem. Daje to człowiekowi nadzieję, ponieważ „potwierdza, że Bóg jest z nami, by nas z mroków grzechu i śmierci wybawić i wskrzesić do życia wiecznego" (EV 29). Drogę uczenia się nadziei człowiek rozpoznaje w Chrystusie, gdy kontemplując Jego mękę, uczy się

${ }^{5}$ Por. A. Gielarowski, Tożsamość chrześcijańska wobec kultury współczesnej, „Ethos” 29(2016) nr 3(115), s. 107.

${ }^{6}$ Por. A. Derdziuk, Modlitwa jako postawa stużenia Ewangelii życia, w: Jan Paweł II, Evangelium vitae. Tekst i komentarze, red. T. Styczeń. J. Nagórny, Lublin 1997, s. 407. 
Jego zawierzenia Ojcu ${ }^{7}$. Dlatego też papież w encyklice o wartości życia prowadzi medytację losu Zbawiciela, zapraszając do tego wszystkich ludzi dobrej woli: „,chciałbym zatrzymać się na chwilę z każdym z was, aby wspólnie kontemplować Tego, którego przebili i który wszystkich przyciąga ku sobie. Patrząc na «widowisko» krzyża, możemy dostrzec w tym chwalebnym drzewie wypełnienie i pełne objawienie całej Ewangelii życia" (EV 50).

Nadzieję na zwycięstwo cywilizacji miłości nad kulturą śmierci budzi też kontemplacja zmartwychwstania, gdy Chrystus objawia swoją zwycięską moc nad grzechem i śmiercią. Papież ukazuje szansę zwycięstwa w ludzkim zmaganiu się o dobro przez odwoływanie się do symboliki paschalnego Baranka: „Baranek złożony w ofierze żyje ze znamionami męki w blasku zmartwychwstania. Tylko On jeden panuje nad wszystkimi wydarzeniami historii: łamie jej «pieczęcie» i utwierdza - w czasie i poza czasem - władzę życia nad śmiercią" (EV 105). Człowiek mający oczy utkwione w Jezusie ma szansę usłyszeć słowo życia, które udziela mu siły do angażowania się w troskę o najbardziej potrzebujących, gdyż wierzy w niezawodną pomoc Bożą.

\section{Wysławianie Ewangelii życia}

Jan Paweł II, będąc świadomy wielkości wyzwania, jakim jest ochrona życia ludzkiego, mobilizował wszystkich ludzi dobrej woli do podjęcia wysiłków na rzecz promocji godności życia. Dla uczniów Chrystusa troska o życie łączy się z dostrzeganiem jego świętości jako rzeczywistości pochodzącej od Boga i zmierzającej do wiecznej komunii w niebie. Dlatego chrześcijanie są wezwani do wysławiania Ewangelii życia pojętej jako dobrej nowiny o człowieku obdarzonym życiem przez miłującego Boga. Wśród form propagowania radosnego orędzia o pięknie życia papież wyliczył: głoszenie, wysławianie oraz służenie Ewangelii życia. Obowiązek ten zostaje wyprowadzony z samego faktu bycia chrześcijaninem, które nierozerwalnie łączy się z byciem ludem życia (por. EV 78-79).

Stwierdzając, że Ewangelia życia oznacza „integralną część Ewangelii, którą jest Jezus Chrystus" (EV 78), papież wzywa do głębszego poznawania Chrystusa i Jego orędzia o życiu, a także zaangażowania się w głoszenie tych prawd. Wysławianie Ewangelii życia dokonuje się przez ukazywanie piękna życia i celebrowanie radości z różnych doświadczeń w biegu ludzkiej egzystencji. Poczynając od modlitwy i kontemplacji tajemnicy Chrystusa, chrześcijanin winien przechodzić do uroczystego obchodzenia rocznic i wyrażania

\footnotetext{
${ }^{7}$ Por. A. Siemieniewski, Ewangelia życia - Ewangelia chwały, w: Życie - dar nienaruszalny. Wokót encykliki Evangelium vitae, red. A. Młotek, T. Reroń, Wrocław 1995, s. 223.
} 
radości z różnych okazji rodzinnych. Papież proponuje podkreślenie dni imienin i urodzin przez bardziej uroczysty ich obchód zwracający uwagę na radość z samego faktu istnienia najbliższych osób w rodzinie. Istotnym wymiarem modlitewnego odniesienia do Boga jest codzienna modlitwa, do której Jan Paweł II wielokrotnie zachęcał na kartach encykliki (por. EV 84, 86, 93, 100). Papież był świadomy, że tylko stała więź z Bogiem może zbudować nową kulturę życia opartą na szacunku dla inności drugiego człowieka.

Szczególną przestrzenią kontaktu z Bogiem, który kształtuje nową jakość odniesień do życia, jest przyjmowanie sakramentów ${ }^{8}$. Ważne jest wykorzystanie okazji przyjmowania sakramentu chrztu i zawierania sakramentu małżeństwa do podkreślenia bliskości z rodzinami, które celebrują nowy etap życia zmierzającego do budowania komunii. Uznanie kruchości człowieka wyrażające się w sakramencie pokuty i pojednania oraz sakramencie namaszczenia chorych łączy się z nadzieją, że Bóg może ofiarować pokrzepienie i pomoc w dźwiganiu się z niemocy duchowej i fizycznej. Celebrowanie Eucharystii, w sposób bezkrwawy uobecniającej zbawczą ofiarę na Krzyżu, staje się świętem rodziny i szkołą miłości społecznej.

W encyklice znalazło się stwierdzenie, że

sakramenty, które są skutecznymi znakami obecności i zbawczego działania Chrystusa Pana w chrześcijańskim życiu: dają ludziom udział w Boskim życiu, zapewniając im potrzebną duchową energię, aby mogli urzeczywistnić pełny i prawdziwy sens życia, cierpienia i śmierci. Celebracje liturgiczne, zwłaszcza sakramentalne, dzięki ponownemu odkryciu autentycznego znaczenia tych obrzędów i ich należytemu docenieniu, będą mogły coraz lepiej wyrażać pełnię prawdy o narodzinach, życiu, cierpieniu i śmierci, pomagając ludziom przeżywać te rzeczywistości jako udział w paschalnej tajemnicy Chrystusa umarłego i zmartwychwstałego (EV 84).

Dlatego tak ważna jest formacja katechetyczna, by chrześcijanie przeżywali sakramenty jako autentyczne spotkanie z Bogiem, które dotyka ich serca i prowadzi do ofiarnej służby?.

Wysławianie Ewangelii życia dokonuje się też przez gesty i symbole zakorzenione w pobożności ludowej, które wyrażają bliskość z innymi i potwierdzają radość istnienia. Szczególnym środowiskiem modlitewnego wspierania troski o życie jest rodzina zbierająca się na wspólną modlitwę na rozpoczęcie dnia i jego zakończenie oraz prosząca o błogosławieństwo przed posiłkiem. Postawę tę propaguje też papież Franciszek, który zachęcał,

8 Por. G. Koch, Sakramentologia - zbawienie poprzez sakramenty, thum. W. Szymona, Kraków 1999, s. 125.

9 Por. Z. Perz, Zobowiazujace wezwanie, w: Sakramenty Kościoła posoborowego, red. H. Bogacki, S. Moysa, Z. Perz, Kraków 1970, s. 271. 
by podziękować Bogu przed i po posiłku. Proponuję wszystkim wierzącym, aby wznowili ten cenny zwyczaj i przeżywali go głęboko. Ta chwila błogosławieństwa, choć bardzo krótka, przypomina nam o naszej zależności od Boga, umacnia nasze poczucie wdzięczności za dary stworzenia, wyrażając uznanie dla tych, którzy swoją pracą zapewniają te dobra, oraz ugruntowuje solidarność z najbardziej potrzebującymi ${ }^{10}$.

Błogosławienie dzieci przez rodziców i otaczanie ich wsparciem modlitewnym nie tylko wskazuje zależność ludzi od Boga, ale też ukazuje rodzicom, że dzieci nie są ich własnością, ale darem od Boga. Dlatego chrześcijańscy rodzice wychowują swoje dzieci do przetwarzania świata i do służby bliźniemu jako Bożego włodarstwa powierzonego ludzkości przez Stwórcę.

Interesującymi papieskimi inicjatywami wspierającymi troskę o życie jest Dzień Świętości Życia oraz Światowy Dzień Chorego. Obie te inicjatywy mają na celu podjęcie refleksji nad kwestią życia, zdrowia i cierpienia oraz gromadzenie się na modlitwę w ramach marszów dla życia i rodziny. Radosne przeżywanie Eucharystii wzmacnia wspólnotę członków ruchów pro-life i umacnia ich w przekonaniu, że uczestniczą w paschalnym zwycięstwie Chrystusa, który na ołtarzu oddaje się cały w postaciach chleba i wina.

Ukazywanie przez papieża modlitwy jako narzędzia w krzewieniu kultury życia i cywilizacji miłości rodzi się z głębokiego przekonania o zależności człowieka od Boga i prowadzi do zawierzenia Stwórcy wszystkich działań podejmowanych przez chrześcijan. Prostota wiary polskiego papieża ujawniła się w treści encykliki, gdy prowadził on medytację nad dziełem Bożym w świecie, podążając drogą tajemnic życia Jezusa Chrystusa ukazanego na kartach Ewangelii. Rozpoczynając od tajemnicy narodzenia, przez kontemplację ziemskiej działalności Zbawiciela, Jan Paweł II zatrzymuał się dłużej nad męką i śmiercią Odkupiciela, dostrzegając we wszystkich zbawczych dziełach Chrystusa wielkie dowartościowanie ludzkiej osoby. Poznając bowiem godność człowieka przez pryzmat miłosiernej miłości Boga angażującej się w wyzwolenie człowieka z niewoli grzechu i uczynienie go dyspozycyjnym w miłości, Ojciec Święty przekonywał czytelników encykliki do podjęcia troski o życie jako wymogu wierności chrześcijańskiemu orędziu, które on nazywa Ewangelią życia.

${ }^{10}$ Por. Franciszek, Encyklika Laudato si', Watykan 2015, nr 227. 


\section{PRAYER AS A TOOL FOR BUILDING A NEW CULTURE OF LIFE}

\section{Summary}

Protecting of human life from conception until to natural death is part of the ongoing spiritual struggle between the culture of death and the civilization of love. The destruction of life is the fruit of the negation of God and the attempt to take over the work of creation. The tool in the hands of believers is the prayer that brings man to God and contemplates his work of creation and salvation in Christ and elevating the human person to the dignity of the child of God. The exhortation of the Gospel of life promoted by St John Paul II in the encyclical Evangelium Vitae leads to perception of its value and prevents the banalization of human behavior in the face of suffering.

Słowa kluczowe: teologia moralna; życie; modlitwa; godność osoby

Keywords: moral theology; life; prayer; the dignity of the person

\section{BIBLIOGRAFIA}

Bajda J., Obrona życia w duchu nadprzyrodzonym - w ujęciu Jana Pawła II, http://dadp.niepokalanow.pl/da_u_jp2/da_u_jp2.2.html [dostęp: 6.02.2017].

Derdziuk A., Modlitwa jako postawa stużenia Ewangelii życia, w: Jan Paweł II, Evangelium vitae. Tekst i komentarze, red. T. Styczeń, J. Nagórny, Lublin 1997, s. 401-415.

Franciszek, Encyklika Laudato si', Watykan 2015.

Gielarowski A., Tożsamość chrześcijańska wobec kultury współczesnej, „Ethos” 29(2016) nr 3(115), s. 93-108.

Jan Paweł II, Homilia podczas Mszy świętej. Koszalin kościół Świętego Ducha 1.06.1991, „L'Osservatore Romano" 11(1991) nr spec, s. 7-8.

Koch G., Sakramentologia - zbawienie poprzez sakramenty, tłum. W. Szymona, Kraków: Wydawnictwo M 1999.

Perz Z., Zobowiąujace wezwanie, w: Sakramenty Kościoła posoborowego, red. H. Bogacki, S. Moysa, Z. Perz, Kraków: WAM 1970, s. 270-296.

Przekroczyć próg nadziei. Jan Pawet II odpowiada na pytania Vittoria Messoriego, Lublin: RW KUL 1994.

Ratzinger J., Jezus z Nazaretu. Studia o chrystologii: t. 1, cz. 1, tłum. M. Górecka, W. Szymona, Lublin: Wyd. KUL 2015.

Siemieniewski A., Ewangelia życia - Ewangelia chwaty, w: Życie - dar nienaruszalny. Wokół encykliki Evangelium vitae, red. A. Młotek, T. Reroń, Wrocław 1995, s. 219-225.

AndrzeJ Derdziuk, ur. 1962 r., członek Warszawskiej Prowincji Zakonu Braci Mniejszych Kapucynów. Profesor zwyczajny doktor habilitowany nauk teologicznych. Pracownik Katedry Teologii Moralnej Społecznej w Instytucie Teologii Moralnej KUL. Członek Polskiej Komisji Akredytacyjnej. Specjalizuje się w historii teologii moralnej, spowiednictwie oraz teologii życia konsekrowanego. 